\title{
Children and Adolescents with Knee Pain Need Diagnostics for Osteochondritis Dissecans
}

\section{Christian Konrads* and Thomas Barthel}

Orthopaedic Clinic Koenig-Ludwig-Haus, Center for Musculoskeletal Research, Julius-Maximilians-University Wuerzburg, Brettreichstr-11, 97074 Wuerzburg, Germany

Osteochondritis dissecans (OCD) of the knee is the most common osteochondral lesion. We see this disease particularly in children and adolescents. Patients usually present with unspecific knee pain. The cause of this condition is not completely known. Undiagnosed it can lead to early secondary arthritis.

OCD is a spatially limited pathology of the subchondral bone. An osteochondral fragment demarcates from the adjacent bone and becomes unstable. In the further course of the disease we find a demarcation on the cartilage surface. In end stage the osteochondral fragment dissecates and becomes a loose body in the joint. It can promote mechanical symptoms like joint blockage [1].

In the $16^{\text {th }}$ century Ambroise Paré firstly described loose bodies in knee joints. In 1887 the German surgeon Franz König introduced the designation "osteochondritis dissecans" [2].

Although the etiology ultimately remains unclear, experts believe causes for OCD might be insufficient perfusion of the subchondral bone and repetitive microtraumata [3,4]. Studies in twins suggest a genetic component in etiology [5].

OCD can occur in different joints. Almost always it appears on convex joint surfaces. In $75 \%$ of cases with OCD the knee is involved; followed by ankle, elbow, hip, and shoulder [6,7]. It's prevalence for the knee in the western population is $6 / 10,000$ inhabitants with a peak age between ten and 20 . In up to $80 \%$ of cases with OCD in the knee joint, the pathology is located in the lateral part of the medial femoral condyle; in 15 to $20 \%$ the pathology is located in the lateral femoral condyle [8]. In ten to five percent of all cases with involvement of the knee, OCD is found in the femoral trochlea or patella. Those atypical locations have a worse prognosis than OCD of the medial femoral condyle $[9,10]$. In up to $40 \%$ the pathology involves both knees [11]. According to open or closed growth plates, we differentiate between juvenile or adult OCD; the juvenile form has a better prognosis [12].

Based on experience in our orthopaedic center and due to its unique pathoanatomic course, we recommend to distinguish OCD from other osteochondral lesions like flake fractures $[13,14]$. Classification of OCD is possible on the basis of $\mathrm{x}$-rays, MRI, arthroscopy, or a combination of these [15-18]. In daily practice differentiation between stable or unstable lesions and between intact or broken cartilage surface is important. Synopsis of the mentioned diagnostic instruments with special emphasis on MRI is reasonable respecting the pathoanatomic course. For classification and treatment planning see Tables 1 and 2.

Stable OCD - stage 1 and 2- can be treated by physical conservation $[19,20]$. Non-operative treatment of stage 2 is sometimes unsuccessful, even in young patients with open growth plates. A failure rate of up to $50 \%$ was reported [21]. Then retrograde drilling is indicated in order to improve subchondral perfusion. In unstable OCD - stage 3 and 4regularly operative treatment is indicated.

Crucial differentiation between stage 2 and 3 is possible in T2weighted MRI: a hyperintense line under the dissecate indicates an unstable lesion. An additional instability criterium is discontinuity of the cartilage surface [22]. Figure 1 illustrates such a case, where operative treatment is indicated: (1) debridement of the delimiting sclerosis, (2) cancellous bone grafting from the tibial head, and (3) refixation of the osteochondral fragment in one procedure.

Especially in children and adolescents suffering knee pain without trauma, we need to exclude OCD. After taking history and performing standard clinical examination, MRI is the best non-invasive diagnostic instrument. Its sensitivity and specificity (up to 100\%) are very good and better than $\mathrm{x}$-rays. There is no radiation exposure to the patient.

\begin{tabular}{|c|c|c|c|}
\hline Stage & X-rays & MRI & Arthroscopy \\
\hline I & normal & $\begin{array}{l}\text { cartilage intact, } \\
\text { normal signal change } \\
\text { subchondral }\end{array}$ & normal \\
\hline II & $\begin{array}{l}\text { radiolucency } \\
\text { and sclerosis }\end{array}$ & $\begin{array}{l}\text { hypointense dissecate } \\
\text { demarcation }\end{array}$ & $\begin{array}{l}\text { cartilage on OCD-border } \\
\text { softened, not demarcated }\end{array}$ \\
\hline $\mathrm{III}_{\mathrm{D}}$ & $\begin{array}{l}\text { sclerosis, } \\
\text { demarcated } \\
\text { dissecate in } \\
\text { situ }\end{array}$ & $\begin{array}{c}\text { cartilage demarcation in } \\
\mathrm{T} 1 \text { and hyperintense line } \\
\text { in } \mathrm{T} 2 \text { under the dissecate } \\
\text { in situ }\end{array}$ & $\begin{array}{l}\text { dissecate demarcated, } \\
\text { cartilage on OCD-border } \\
\text { partially or completely } \\
\text { interrupted }\end{array}$ \\
\hline $\mathrm{III}_{\mathrm{M}}$ & $\begin{array}{l}\text { sclerosis, } \\
\text { demarcated } \\
\text { fragmented } \\
\text { dissecate in } \\
\text { situ }\end{array}$ & $\begin{array}{l}\text { cartilage demarcation } \\
\text { in } \mathrm{T} 1 \text { and hyperintense } \\
\text { line in } \mathrm{T} 2 \text { under the } \\
\text { fragmented dissecate }\end{array}$ & $\begin{array}{l}\text { dissecate demarcated and } \\
\text { fragmented, cartilage on } \\
\text { OCD-border partially or } \\
\text { completely interrupted }\end{array}$ \\
\hline $\mathrm{IV}_{\mathrm{D}}$ & $\begin{array}{c}\text { empty } \\
\text { dissecate bed, } \\
\text { loose body }\end{array}$ & $\begin{array}{l}\text { empty dissecate bed, } \\
\text { loose body }\end{array}$ & $\begin{array}{l}\text { empty dissecate bed, loose } \\
\text { body, dissecate fixable }\end{array}$ \\
\hline $\mathrm{IV}_{\mathrm{M}}$ & $\begin{array}{c}\text { empty } \\
\text { dissecate bed, } \\
\text { loose body }\end{array}$ & $\begin{array}{l}\text { empty dissecate bed, } \\
\text { loose body }\end{array}$ & $\begin{array}{l}\text { empty dissecate bed, loose } \\
\text { body, dissecate destroyed }\end{array}$ \\
\hline \multicolumn{4}{|c|}{ D Dissecans; M Malacia, multi-fragmented } \\
\hline
\end{tabular}

Table 1: Classification of osteochondritis dissecans [19].

\begin{tabular}{|c|c|c|}
\hline Stage & Stability & Therapy \\
\hline I & stable & conservative \\
\hline II & stable & retrograde drilling \\
\hline III $_{D}$ & Unstable & bone grafting and refixation \\
\hline III $_{M}$ & Unstable & $\begin{array}{r}\text { bone grafting and refixation (partially) or debridement/partial } \\
\text { debridement, bone grafting, cartilage therapy }\end{array}$ \\
\hline $\mathrm{IV}_{\mathrm{D}}$ & Unstable & bone grafting and refixation \\
\hline $\mathrm{IV}_{\mathrm{M}}$ & Unstable & debridement, bone grafting, cartilage therapy \\
\hline & & D Dissecans; M Malacia, multi-fragmented \\
\hline
\end{tabular}

Table 2: Stage oriented therapy of osteochondritis dissecans of the knee [14]

${ }^{*}$ Corresponding author: Christian Konrads, Orthopaedic Clinic Koenig-LudwigHaus, Center for Musculoskeletal Research, Julius-Maximilians-University Wuerzburg, Brettreichstr-11, 97074 Wuerzburg, Germany, Tel: 004917655207825; E-mail: christian.konrads@gmail.com

Received November 24, 2015; Accepted December 16, 2015; Published December 21, 2015

Citation: Konrads C, Barthel T (2015) Children and Adolescents with Knee Pain Need Diagnostics for Osteochondritis Dissecans. Pain Manage Med 2: 107.

Copyright: ( $) 2015$ Konrads C, et al. This is an open-access article distributed under the terms of the Creative Commons Attribution License, which permits unrestricted use, distribution, and reproduction in any medium, provided the original author and source are credited. 
Citation: Konrads C, Barthel T (2015) Children and Adolescents with Knee Pain Need Diagnostics for Osteochondritis Dissecans. Pain Manage Med 2: 107.

Page 2 of 2

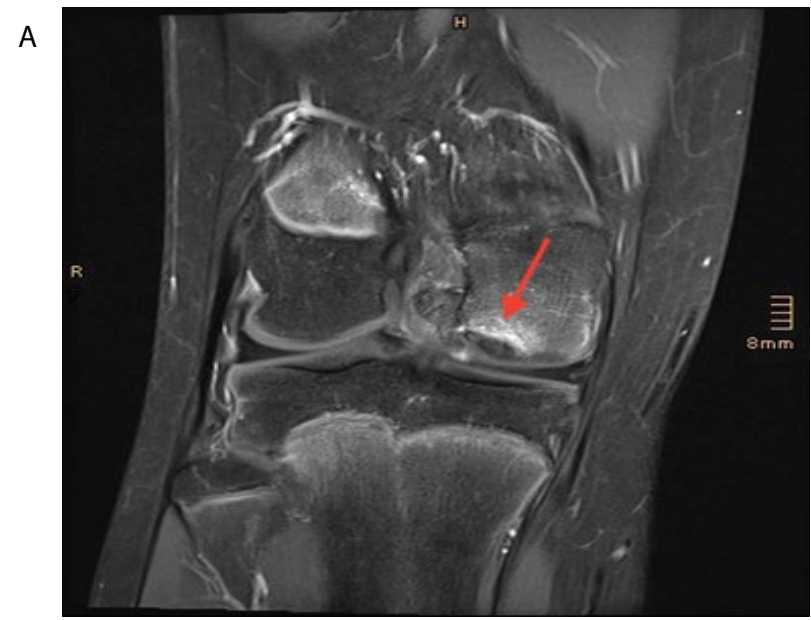

B

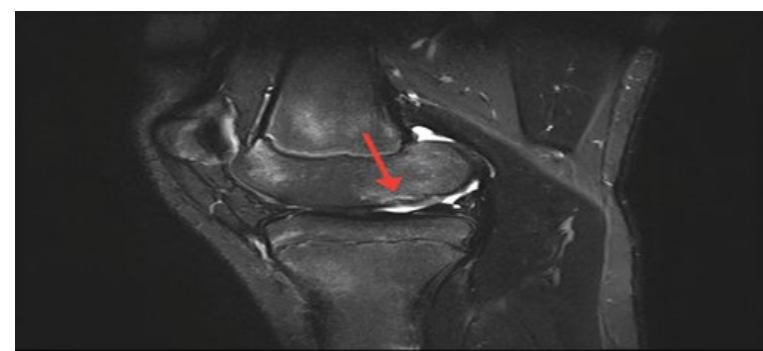

Figure 1 a, b: T2-weighted MRI of a 14-year-old girl's right knee showing unstable juvenile osteochondritis dissecans stage 3D of the medial femoral condyle in frontal (a) and sagittal (b) views. A hyperintense line under the dissecate indicates an unstable lesion (arrow).

Classification and stage depending orthopaedic treatment is important for a good outcome. Untreated OCD can progress leading to severe local joint damage and secondary joint destruction [23].

\section{References}

1. Schenck RC Jr, Goodnight JM (1996) Osteochondritis dissecans. J Bone Joint Surg Am 78: 439-456.

2. König F (2013) The classic: On loose bodies in the joint. 1887. Clin Orthop Relat Res 471: 1107-1115.

3. Shea KG, Jacobs JC Jr, Carey JL, Anderson AF, Oxford JT (2013) Osteochondritis dissecans knee histology studies have variable findings and theories of etiology. Clin Orthop Relat Res 471: 1127-1136.

4. Garrett JC (1991) Osteochondritis dissecans. Clin Sports Med 10: 569-593.
5. Gans I, Sarkissian EJ, Grant SF, Ganley TJ (2013) Identical osteochondritis dissecans lesions of the knee in sets of monozygotic twins. Orthopedics 36 : e1559-1562.

6. Cahill BR (1995) Osteochondritis Dissecans of the Knee: Treatment of Juvenile and Adult Forms. J Am Acad Orthop Surg 3: 237-247.

7. Robertson W, Kelly BT, Green DW (2003) Osteochondritis dissecans of the knee in children. Curr Opin Pediatr 15: 38-44.

8. Flynn JM, Kocher MS, Ganley TJ (2004) Osteochondritis dissecans of the knee. J Pediatr Orthop 24: 434-443.

9. Hefti F, Beguiristain J, Krauspe R, Möller-Madsen B, Riccio V, et al. (1999) Osteochondritis dissecans: a multicenter study of the European Pediatric Orthopedic Society. J Pediatr Orthop B 8: 231-245

10. Peterson L, Minas T, Brittberg M, Lindahl A (2003) Treatment of osteochondritis dissecans of the knee with autologous chondrocyte transplantation: results at two to ten years. J Bone Joint Surg Am 85-85A Suppl 2: 17-24.

11. Kutscha-Lissberg F, Singer P, Vécsei V, Marlovits S (2004) [Osteochondritis dissecans of the knee joint]. Radiologe 44: 783-788.

12. Federico DJ, Lynch JK, JokI P (1990) Osteochondritis dissecans of the knee: a historical review of etiology and treatment. Arthroscopy 6: 190-197.

13. Detterline AJ, Goldstein JL, Rue JP, Bach BR Jr (2008) Evaluation and treatment of osteochondritis dissecans lesions of the knee. J Knee Surg 21 : 106-115.

14. Konrads C, Schultheiß J, Reppenhagen S, Rudert M, Barthel T (2015) [Why does the knee hurt?]. MMW Fortschr Med 157: 53-56.

15. Bohndorf K (1998) Osteochondritis (osteochondrosis) dissecans: a review and new MRI classification. Eur Radiol 8: 103-112.

16. Dipaola JD, Nelson DW, Colville MR (1991) Characterizing osteochondral lesions by magnetic resonance imaging. Arthroscopy 7: 101-104.

17. Guhl JF (1982) Arthroscopic treatment of osteochondritis dissecans. Clin Orthop Relat Res : 65-74.

18. Mesgarzadeh M, Sapega AA, Bonakdarpour A, Revesz G, Moyer RA, et al. (1987) Osteochondritis dissecans: analysis of mechanical stability with radiography, scintigraphy, and MR imaging. Radiology 165: 775-780.

19. Bruns J (1997) [Osteochondrosis dissecans]. Orthopade 26: 573-584.

20. Wall EJ, Vourazeris J, Myer GD, Emery KH, Divine JG, et al. (2008) The healing potential of stable juvenile osteochondritis dissecans knee lesions. J Bone Joint Surg Am 90: 2655-2664.

21. Krause M, Hapfelmeier A, Möller M, Amling M, Bohndorf K, et al. (2013) Healing predictors of stable juvenile osteochondritis dissecans knee lesions after 6 and 12 months of nonoperative treatment. Am J Sports Med 41: 2384-2391.

22. O'Connor MA, Palaniappan M, Khan N, Bruce CE (2002) Osteochondritis dissecans of the knee in children. A comparison of MRI and arthroscopic findings. J Bone Joint Surg Br 84: 258-262.

23. Kijowski R, Blankenbaker DG, Shinki K, Fine JP, Graf BK, et al. (2008) Juvenile versus adult osteochondritis dissecans of the knee: appropriate MR imaging criteria for instability. Radiology 248: 571-578. 